\title{
Home Range Characteristics and Diel Patterns in Space Use of Mutton Snapper, Lutjanus Analis, in St. Thomas, Us Virgin Islands
}

\section{Sarah L. Heidmann ( $\nabla$ sarah.heidmann@uvi.edu )}

Center for Marine and Environmental Studies, University of the Virgin Islands, 2 John Brewers Bay, St. Thomas, VI 00802, USA https://orcid.org/0000-0002-0729-0229

Jonathan Jossart

CSS-Dynamac

Richard S. Nemeth

University of the Virgin Islands

Telemetry case report

Keywords: acoustic telemetry, home range, US Virgin Islands, movement ecology, Lutjanidae, Lutjanus analis

Posted Date: October 8th, 2020

DOl: https://doi.org/10.21203/rs.3.rs-86898/v1

License: (1) (1) This work is licensed under a Creative Commons Attribution 4.0 International License. Read Full License

Version of Record: A version of this preprint was published at Animal Biotelemetry on April 16th, 2021. See the published version at https://doi.org/10.1186/s40317-021-00237-z. 


\section{Abstract}

Background: The movement ecology of mutton snapper Lutjanus analis is poorly understood despite their ecological and economic importance in the Caribbean. Passive acoustic telemetry was used to determine home ranges of six adult $L$. analis, including diel patterns, in Brewers Bay, St. Thomas, US Virgin Islands. Understanding long-term space use, including site fidelity and habitat usage, is necessary to implement effective and appropriate management actions for a species with extensive space and resource needs.

Results: Individual L. analis were tracked over an average period of 316 days (range 125 - 509 days) and showed high site fidelity to relatively small home ranges (mean \pm SD: $0.103 \pm 0.028 \mathrm{~km}^{2}$, range $0.019-0.190 \mathrm{~km}^{2}$ ) and core use areas with low overlap among individuals. Most home ranges had a habitat composition dominated by seagrass and to a lesser degree, coral reef and/or pavement. Nighttime activity spaces were distinct from but contained within daytime areas.

Conclusions: Mutton snapper showed strong site fidelity to home ranges in Brewers Bay. Two individuals that were absent from the array for more than a few hours were detected at separate arrays at spawning aggregation sites. This study expands upon knowledge of mutton snapper home range characteristics, highlights the importance of maintaining adjacent high-quality habitat types in any spatial management plan, and encourages the adoption of other types of management strategies, particularly for transient-aggregating species.

\section{Background}

The movement patterns of animals examined in the context of their surroundings reveal central aspects of their life history and resource needs. Coral reef fish, in particular, live in highly heterogeneous environments, making diel movements between habitat types in order to balance predation risk, foraging benefits, and competition avoidance [1,2]. The mosaic of habitats inhabited by a fish comprises their home range, an area regularly utilized for feeding and shelter [3]. Analysis of reef fish movement patterns demonstrates direct connectivity across different habitat types for certain reef fish families [4], a life history strategy that promotes survival of the individual and influences overall productivity and reef health in visited areas [5].

Studies using visual surveys have shown that spatial distributions of fish can be predicted by underlying habitat type and condition [6]. This type of assessment is limited, however, in that it is affected by observer presence, usually represents a single time point, and is difficult to link to other environmental variables such as temperature or tidal phase. For general long-term, coarse-scale movement patterns and space utilization analysis, passive acoustic telemetry is a well-suited method [7], which allows the tracking of many fish continuously over a long period of time $[8,9]$. This technology can help identify important parameters of fish ecology and life history such as diel changes in space use [1, 4, 10, 11], habitat association [12, 13], site fidelity [14], residence time [15], and seasonal migrations [16].

Members of the coral-reef-associated fish family Lutjanidae have been shown to have high site fidelity and a relatively small home range $[4,12]$, so their movements should display a strong association with a small area within their home range. Lutjanid abundance is higher in specific edge habitats, such as areas with abundant patch reefs and large amounts of seagrass [6, 17], presumably because the proximity of usable resources signifies higher-quality habitat than structure alone [18]. Lutjanids and Haemulids have been shown to predictably use multiple habitats within a day, performing diel movements between coral reefs, where they shelter during the day, and seagrasses, where they forage at night $[1,4,19]$. Therefore, an individual's home range would be expected to contain a large proportion of each of these habitats, with daytime and nighttime activity spaces dominated by coral reef and seagrass habitats, respectively.

Mutton snapper, Lutjanus analis (Cuvier, 1828), are economically important to Caribbean fishers that target nearshore reef fish. In the northern US Virgin Islands, this species comprised an average of $18 \%$ by weight of commercial snapper landings between 2011 and 2017 (USVI Department of Planning and Natural Resources, unpublished data). The species is classified as "Near Threatened" by the International Union for Conservation of Nature due to trends of decreasing estimated population sizes throughout its range [20]. This is due, at least in part, to their reproductive strategy of aggregating at predictable times and locations in large groups for spawning. These transient fish spawning aggregations occur after the full moon in March through 
July, during which the species is highly vulnerable to fishing [21,22]. When not aggregating, individuals are solitary and territorial [23], and are found in a wide variety of habitats. This species undergoes ontogenetic shifts in primary habitat association, with juveniles being found mainly in nearshore seagrass beds and adults in coastal or offshore habitats over hard substrate [24]. In the Dry Tortugas, Florida, adults are usually observed over hard bottom, swimming actively along reef edges [25], and are also often observed in these locations in St. Thomas (S. L. Heidmann, pers. obs.).

L. analis are generalist predators, opportunistically feeding mainly on arthropods such as crabs and shrimp, gastropods, and reef fish [26], with individual variability in foraging style to reduce intraspecific competition [23]. It has been shown that $L$. analis have temporal diet variations based on prey availability [27, 28], and therefore the species is ecologically important for top-down control over prey populations. This species is known to be more mobile than some comparably sized benthic-associated grouper species, but retain high site fidelity [25].

With size-at-maturity estimates ranging from $28.0 \mathrm{~cm}$ to $52.0 \mathrm{~cm}[28,29,30], \mathrm{L}$. analis are likely to utilize a larger home range size than well-studied smaller species of snapper because of associated increased mobility and resource needs [31, 32], but previous studies of this species have been limited in acoustic receiver array continuity. A long-term tracking study by Farmer and Ault [33] obtained location data from a single mutton snapper for 168 days and estimated its home range size at $7.64 \mathrm{~km}^{2}$, but this estimate included two long-distance presumed spawning migrations which were unrepresentative of routine movements. Another study by Feeley et al. [34] identified home range areas, excluding observed spawning migrations, for 13 resident $L$. analis at a mean size of $2.5 \mathrm{~km}^{2}$. Both these studies had non-overlapping array coverage over a large area, which may inflate home range estimates. Additionally, these studies contained only a cursory description of home range characteristics and finer-scale movements, which are not currently well-understood in this species.

To quantitatively describe $L$. analis movement patterns, this study used passive acoustic telemetry and spatial analysis tools on an individual level to 1) determine home range characteristics and degree of site fidelity and 2) examine diel, daily, and seasonal changes in space use. Based on characteristics of other snapper species, we hypothesized that $L$. analis display high site fidelity to a home range that is smaller than previous estimates, and that each has a nighttime activity space comprising seagrass beds in which they forage, which is larger than and separate from a coral-reef-dominated daytime activity space.

\section{Methods}

\section{Study Site and Acoustic Receiver Array}

An array of 43 omnidirectional acoustic receivers (69 kHz; Model VR2W, VEMCO, AMIRIX Systems Inc., Halifax, Nova Scotia) was deployed in Brewers Bay (Fig. 1), on the south side of St. Thomas, US Virgin Islands (USVI). Brewers Bay faces southwest, and is approximately $0.9 \mathrm{~km}^{2}$ in area, with depths from 0 to $27 \mathrm{~m}$ that increase gradually from northeast to southwest. Temperature is fairly homogenous across Brewers Bay, with a mean annual temperature of $28.6 \pm 0.002{ }^{\circ} \mathrm{C}$ (mean $\pm \mathrm{SE}$, range $25.2-31.8^{\circ} \mathrm{C}$; $\mathrm{R}$. Nemeth unpublished data).

The benthic habitats of the bay were delineated and mapped by digitizing LiDAR bathymetry and both aerial and satellite imagery. This characterization was validated using drop camera imagery, following previous methods used by NOAA [35, 36]. The substrate of the bay is composed of several habitat types, categorized for the purpose of this study as coral reef, seagrass (comprising the native Thalassia testudinum and Syringodium filiforme, and the invasive Halophila stipulacea), sand with scattered coral and rock, artificial, pavement, and other (i.e., bare sand, algae, mud) (Fig. 1).

Range testing was performed in June of 2015 to determine detection probabilities around the bay to account for variability in acoustic transmission across shifting environmental conditions and degrees of habitat complexity [37, 38, 39]. A general detection probability of $70 \%$ (based on V 9 transmitters) was used to determine spacing of receivers for the final array configuration. For the V13 transmitters used in this study, this resulted in highly overlapping estimated $70 \%$ detection ranges, of between 101 and $120 \mathrm{~m}$ radius depending on location. This maximized coverage of the bay with a limited number of receivers and provided an overall maximum detection probability of $91 \%$ under optimal conditions when a fish was inside overlapping detection ranges [37]. 
Moorings were placed at depths between $2 \mathrm{~m}$ and $27 \mathrm{~m}$ and constructed using sand screws and cinder blocks with subsurface buoys, as well as existing no-wake buoys and swim buoys. The body of each receiver was wrapped in electrical tape for easy removal of biofouling that could grow over the hydrophone and affect detection efficiency [40]. Receivers were retrieved, cleaned, data were downloaded into the VUE software [41] and batteries replaced approximately every four months over the duration of the 19-month study. Temperature was recorded every 15 minutes on a subset of the receiver moorings using 22 HOBO Water Temp Pro v2 (Onset Computer Corporation, Bourne, MA), and 5 miniDOT loggers (Precision Measurement Engineering, Vista, CA).

\section{Fish Tagging Methods}

Lutjanus analis were caught using Antillean fish traps and hook and line baited with squid at various locations within Brewers Bay. Total length $(T L)$ and fork length $(F L)$ were measured for each captured individual. The sex of each fish was not determined due to a lack of sexual dimorphism in this species. Incidence of barotrauma was minimal, due to the relatively shallow depths of traps and hook and line fishing locations. Fish were implanted with a VEMCO V13 acoustic transmitter (codespace A69-1601; $13 \mathrm{~mm}$ diameter, $36 \mathrm{~mm}$ long, $6 \mathrm{~g} ; 69 \mathrm{kHz}, 147 / 153 \mathrm{~dB}, 30-250 \mathrm{~s}$ delay, estimated battery life 365-653 days) using surgical insertion, which has a longer retention time than force feeding, and minimizes drag and fouling compared to external attachment [9]. No anesthetic was used in order to minimize handling and recovery time and ensure no additional risk of predation due to aftereffects [42]. Fish were inverted in a tub of aerated seawater to induce tonic immobility. A $1.5 \mathrm{~cm}$ incision was made approximately $1 \mathrm{~cm}$ from and parallel to the ventral midline. The acoustic transmitter was coated in triple antibiotic ointment and inserted into the peritoneal cavity. The incision was closed using 2-3 chromic gut or silk surgical sutures or staples and covered with triple antibiotic ointment. Fish were observed for at least two minutes to ensure recovery before being released at the surface near their catch location. After release, all individuals swam immediately down and out of sight.

\section{Data Processing}

Detections from each fish were examined for insufficient data or abnormal behavioral patterns, such as a sharp decrease in activity or consistent detections only at a couple adjacent receivers over several weeks, which implied transmitter loss, predation, or mortality. In these cases, transmitters were either excluded entirely from analysis due to insufficient detections (i.e. 36029, 45336), or detections were removed after a presumed predation event (i.e. 59271). Detections at separate arrays outside Brewers Bay were noted but, as they represented extraordinary movements, were not included in home range estimations.

All data processing and analyses were performed in the R 3.6 programming language [43] through the RStudio environment [44]. Detection data from the day of tagging as well as the following full day were not used in analyses. Each detection was categorized into daytime, nighttime, and crepuscular activity based on daily sunrise and sunset times [45] with crepuscular considered to be within an hour before or after sunrise or sunset. Detection data from crepuscular periods were used for calculation of home ranges, but not for day/night activity spaces, because detection rates on reefs in the USVI have been shown to drop substantially during crepuscular periods due to increases in ambient noise, potentially obscuring any patterns in activity during these times [38].

To reduce the influence of variable detection rates and false detections resulting from signal collisions, as well as to enhance position estimates, detections were pooled into hourly short-term center of activity (COA) locations. The COA locations of each fish were calculated using the mean-position algorithm described by Simpfendorfer et al. [7], as the arithmetic mean of the latitude and longitude positions of the receivers that recorded each valid detection within each hour. This time period was chosen as it was long enough to expect 5-20 detections per fish even if all tagged fish were near the same receiver at the same time [46], without unduly decreasing data resolution.

\section{Spatial Analysis}

Site fidelity was determined by calculating a residence index (RI) within the array for each fish, as the total number of days the fish was detected divided by the number of days between the first and last detections [47]. The RI varied between 0 for no residency and 1.0 for absolute residency. An hourly RI was also calculated to ensure home range estimations were comprehensive and not limited by the extent of the array. 
Home ranges were estimated from COA locations using the R package adehabitatHR [48] to calculate $95 \%$ minimum convex polygons (MCPs) and 95\% Brownian Bridge movement models (BBMMs) for each tracked mutton snapper, chosen to illustrate most daily movements and exclude infrequent longer-distance migrations. The same methodology was used to create $50 \%$ MCPs, which represent each fish's smaller core use area, and to create $95 \%$ MCPs for daytime and nighttime activity spaces. MCPs were computed by creating the smallest convex polygon around $95 \%$ of the input data and illustrated the extent of the most common space used by each fish. BBMMs were computed by modeling conditional random walks between successive locations, dependent on the time and distance between each pair of locations and accounting for Brownian motion variance; this method described the expected movement paths of each animal by producing a rasterized map of the probability of occurrence. BBMMs were chosen as a comparison method to the more common MCP (i.e. $[7,8,33]$ ) as it is less frequently used, but provides more detailed information about space use, including paths between successive relocations, allowing the identification of movement corridors [49].

Because MCPs are heavily influenced by sample size [50], all home ranges and activity spaces were calculated using 2770 randomly selected COAs, the smallest overall sample size. All points were used in calculating BBMMs, as they are less sensitive to sample size and account for paths between consecutive points. Smoothing parameters for BBMMs were calculated using the standard deviation of the distances between relocations (sig2, the approximate location error), and a maximum likelihood estimation (sig1, the estimated Brownian motion variance). The sizes of MCPs were compared to those of BBMMs using a t-test paired by individual. Degree of territoriality in Brewers Bay was determined using an overlap index (OI) of $50 \%$ core use areas, calculated as the total area of polygons overlap divided by the combined area of all polygons, with possible values ranging from 0.0 (no overlap) to 1.0 (100\% overlap).

The sizes of daytime and nighttime activity spaces were compared using a one-tailed t-test paired by individual, with the alternative hypothesis that nighttime spaces were larger than daytime ones. To evaluate the degree of spatial segregation between these activity spaces for each individual, an Ol was calculated, as well as the distance between center-of-mass centroids of day and night $95 \%$ MCPs. Activity levels were compared on an hourly basis across day and night with a t-test paired by individual, using as proxies first the number of detections, then the number of stations receiving detections.

Habitat composition of $L$. analis home ranges and day/night activity spaces was determined by overlaying the $95 \%$ MCPs on the benthic habitat map of Brewers Bay and calculating the percent coverage of each habitat type. A habitat selection index (HSI) was used to determine preference or avoidance of each habitat by each fish. The index was calculated by dividing the percent coverage of each habitat in an MCP by the percent coverage of each habitat type available, such that the degree of positive or negative deviation from a neutral value of 1 indicates preference or avoidance [51]. The HSI of each habitat type across all home ranges was tested against the neutral value of 1 with a Mann-Whitney-Wilcoxon test to evaluate selection of that habitat, and differences between daytime and nighttime activity spaces were tested with a paired Mann-Whitney-Wilcoxon test.

To test whether $L$. analis were selecting for specific temperature ranges, a frequency distribution of available temperatures across the entire study period, scaled to a probability density, was compared to a similar distribution of temperatures at which fish were present, using a two-sample Kolmogorov-Smirnov test.

Daily and seasonal changes in space usage were analyzed with two iterations of a repeated measures PERMANOVA using the adonis function in the R package vegan [52]. Receiver usage composition, defined as presence/absence at each receiver across the array at each time point, was tested over time using the Jaccard index. The longest period of overlapping tracking time for the largest number of fish was used in the test, which was for five fish over seven months from November 2016 through May 2017. During this period, receiver presence composition for each fish was compared across months, using 999 unique permutations to develop a distribution for computing the pseudo-F statistic, then again across 220 days for each fish, compared to a distribution developed with 31 unique permutations.

\section{Results}

Eight individual L. analis were tagged opportunistically between September 2015 and November 2016. Sizes ranged from $37.5 \mathrm{~cm}$ to $69.0 \mathrm{~cm}$ TL (Table 1), with a mean of $48.6 \pm 3.8 \mathrm{~cm}$ TL (mean \pm SEM, same throughout manuscript). The first 
detection of any fish in the study was on 12 September 2015, and the last on 8 November 2017. Over the course of the study, at least one individual was detected at 39 of the 43 receivers in the array, with each fish detected at between 0 and 29 receiver stations per day (Fig. 2).

Table 1. Total length (TL), tag date, and summary of tracking data from Lutjanus analis tagged in Brewers Bay, St. Thomas, sorted by date tagged. Information sorted by tagging date.

* data excluded from analysis

$\nabla$ data after $6 / 16 / 16$ removed due to suspected predation

\begin{tabular}{|llllllllll|}
\hline Transmitter & $\begin{array}{l}\text { TL } \\
(\mathbf{c m})\end{array}$ & $\begin{array}{l}\text { Tag date } \\
\text { (mm/dd/yy) }\end{array}$ & $\begin{array}{l}\text { Total no. } \\
\text { detections }\end{array}$ & $\begin{array}{l}\text { Date of } \\
\text { first } \\
\text { detection }\end{array}$ & $\begin{array}{l}\text { Date of } \\
\text { last } \\
\text { detection }\end{array}$ & $\begin{array}{l}\text { Residence } \\
\text { Index (RI) }\end{array}$ & $\begin{array}{l}\text { Hourly } \\
\text { Residence } \\
\text { Index }\end{array}$ & $\begin{array}{l}\text { Total } \\
\text { stations } \\
\text { detected }\end{array}$ & $\begin{array}{l}\text { Mean } \\
\text { no. } \\
\text { stations } \\
\text { detected } \\
\text { per day }\end{array}$ \\
\hline$* 36029$ & 69 & $09 / 10 / 15$ & 9363 & $9 / 12 / 15$ & $9 / 29 / 15$ & 1.0 & 0.99 & 17 & 9.3 \\
\hline 059271 & 38.1 & $02 / 11 / 16$ & 26432 & $2 / 13 / 16$ & $6 / 16 / 16$ & 1.0 & 0.92 & 15 & 6.1 \\
\hline 24797 & 48 & $06 / 16 / 16$ & 89799 & $6 / 18 / 16$ & $11 / 8 / 17$ & 1.0 & 0.78 & 32 & 3.4 \\
\hline$* 45336$ & 50 & $08 / 15 / 16$ & 168 & $8 / 18 / 16$ & $7 / 16 / 17$ & 0.32 & 0.02 & 4 & 0.4 \\
\hline 45337 & 37.5 & $08 / 24 / 16$ & 434939 & $8 / 26 / 16$ & $7 / 30 / 17$ & 1.0 & 1.0 & 30 & 20.8 \\
\hline 45338 & 45.6 & $09 / 30 / 16$ & 546511 & $10 / 2 / 16$ & $7 / 30 / 17$ & 0.94 & 0.93 & 38 & 15.9 \\
\hline 45339 & 42.5 & $09 / 30 / 16$ & 1093389 & $10 / 2 / 16$ & $11 / 8 / 17$ & 1.0 & 1.0 & 38 & 21.8 \\
\hline 45334 & 58.2 & $11 / 1 / 16$ & 475774 & $11 / 3 / 16$ & $6 / 10 / 17$ & 1.0 & 1.0 & 33 & 20.3 \\
\hline
\end{tabular}

The six L. analis used in analyses were tracked from their date of tagging for as long as possible, resulting in tracking duration ranging between 125 and 509 days (Table 1), with a mean tracking time of $316 \pm 55$ days. All individuals but one (45338) were detected on the Brewers Bay array every day between their first and last detection in Brewers Bay, which resulted in RI values of 1.0. Individual 45338 had an RI of 0.94, due to two periods of absence from the Brewers Bay array in June and July of 2017, each lasting approximately one week. During these periods, this fish was detected at arrays at the Grammanik Bank and Tampo (Fig. 1), two sites on the edge of the southern Puerto Rican shelf at $15 \mathrm{~km}$ and $30 \mathrm{~km}$ distance from Brewers Bay, respectively. One additional fish (45334), that was tracked continuously for 220 days in Brewers Bay (RI = 1.0), was also detected at the Tampo array for 12 hours, but never returned to Brewers Bay afterward. Hourly RI values for all individuals were greater than 0.9 except in one case $(24797 ; \mathrm{RI}=0.78)$ (Table 1$)$.

Both $95 \%$ and $50 \%$ MCPs showed different home range sizes and locations across tagged fish within Brewers Bay (Fig. 3), with an Ol of 0.11 among $50 \%$ MCPs. Full $95 \%$ MCPs were between $0.019 \mathrm{~km}^{2}$ and $0.190 \mathrm{~km}^{2}$ with a mean of $0.103 \pm 0.028 \mathrm{~km}^{2}$, while $50 \%$ core use MCPs were between $0.004 \mathrm{~km}^{2}$ and $0.064 \mathrm{~km}^{2}$ with a mean of $0.030 \pm 0.011 \mathrm{~km}^{2}$ (Table 2). Home range estimation using BBMMs yielded polygons of similar location but different size and shape than MCPs (Fig. 3). 95\% BBMMs were between $0.096 \mathrm{~km}^{2}$ and $0.270 \mathrm{~km}^{2}$, with a mean of $0.168 \pm 0.028 \mathrm{~km}^{2}$, which were significantly larger than $95 \%$ MCPs across all individuals $\left(t_{5}=-3.62, p=0.02\right)$. 
Table 2

Area and habitat composition of home ranges of tracked Lutjanus analis, created using $95 \%$ and $50 \%$ minimum convex polygons (MCPs) and Brownian bridge movement models (BBMMs). Percent habitat composition was derived from the intersection of MCPs with the benthic habitat map, and categorized as seagrass, coral reef, pavement and other (bare sand, artificial); habitat selection index (HSI) is indicated in parentheses for each habitat type in 95\% MCPs.

\begin{tabular}{|c|c|c|c|c|c|c|c|}
\hline Transmitter & Level (\%) & $\mathrm{MCP}\left(\mathrm{km}^{2}\right)$ & BBMM $\left(\mathrm{km}^{2}\right)$ & $\begin{array}{l}\text { Seagrass } \\
\%(H S I)\end{array}$ & $\begin{array}{l}\text { Coral Reef } \\
\%(H S I)\end{array}$ & $\begin{array}{l}\text { Pavement } \\
\% \text { (HSI) }\end{array}$ & $\begin{array}{l}\text { Other } \\
\%(\mathrm{HSI})\end{array}$ \\
\hline \multirow[t]{2}{*}{24797} & 95 & 0.019 & 0.145 & $75.1(1.4)$ & $0(0)$ & $24.9(2.8)$ & $0(0)$ \\
\hline & 50 & 0.004 & 0.019 & 95.7 & 0 & 4.3 & 0 \\
\hline \multirow[t]{2}{*}{45334} & 95 & 0.126 & 0.144 & $91.0(1.7)$ & $9.0(1.6)$ & $0(0)$ & $0(0)$ \\
\hline & 50 & 0.063 & 0.029 & 89.6 & 10.4 & 0 & 0 \\
\hline \multirow[t]{2}{*}{45337} & 95 & 0.168 & 0.320 & $62.4(1.2)$ & $19.9(3.5)$ & $17.7(2.0)$ & $0(0)$ \\
\hline & 50 & 0.064 & 0.062 & 58.2 & 15.3 & 26.6 & 0 \\
\hline \multirow[t]{2}{*}{45338} & 95 & 0.190 & 0.286 & $94(1.7)$ & $6(1.1)$ & $0(0)$ & $0(0)$ \\
\hline & 50 & 0.021 & 0.034 & 100 & 0 & 0 & 0 \\
\hline \multirow[t]{2}{*}{45339} & 95 & 0.075 & 0.092 & $93.8(1.7)$ & $6.2(1.1)$ & $0(0)$ & $0(0)$ \\
\hline & 50 & 0.018 & 0.019 & 93.5 & 6.5 & 0 & 0 \\
\hline \multirow[t]{2}{*}{59271} & 95 & 0.040 & 0.106 & $89.4(1.7)$ & $0(0)$ & $10.6(1.2)$ & $0(0)$ \\
\hline & 50 & 0.012 & 0.022 & 91.4 & 0 & 8.6 & 0 \\
\hline
\end{tabular}

Daytime $95 \%$ MCPs were between $0.041 \mathrm{~km}^{2}$ and $0.195 \mathrm{~km}^{2}$, with a mean of $0.103 \pm 0.026 \mathrm{~km}^{2}$, while nighttime $95 \%$ MCPs were between $0.010 \mathrm{~km}^{2}$ and $0.036 \mathrm{~km}^{2}$, with a mean of $0.021 \pm 0.004 \mathrm{~km}^{2}$ (Table 3). Nighttime activity spaces were significantly smaller than daytime activity spaces across all individuals $\left(t_{5}=3.28, p=0.02\right)$; on average, a nighttime space was $25 \%$ of the size of its corresponding daytime space, ranging from $7-42 \%$ of the size. Nighttime activity spaces either strongly overlapped or were contained within daytime activity spaces (Fig. 4), resulting in a mean overlap index of $0.20 \pm 0.05$ (range 0.07 to 0.36 ; Table 3 ). Day and night centroid separation distances were between $47 \mathrm{~m}$ and $274 \mathrm{~m}$ (mean $142 \pm 40 \mathrm{~m}$ ). L. analis were detected at more receiver stations per hour during the day than during the night $\left(t_{1896}=23.6, p<0.001\right)$ and there were overall more detections per hour during the day than night $\left(\mathrm{t}_{1896}=5.6, \mathrm{p}<0.001\right)$. A Spearman's rank showed a significant correlation between number of receiver stations per hour and number of detections per hour (rho $=0.95, p<0.001)$. 
Table 3

Characteristics of daytime and nighttime activity spaces of tracked Lutjanus analis, created using 95\% MCPs. Statistics include day to night overlap index, activity space size ratio, centroid separation distance, size $\left(\mathrm{km}^{2}\right)$, and habitat composition. Percent habitat composition was derived from the benthic habitat map, and categorized as seagrass, coral reef, pavement and other (bare

\begin{tabular}{|c|c|c|c|c|c|c|c|c|c|}
\hline Transmitter & $\begin{array}{l}\text { Overlap } \\
\text { Index }\end{array}$ & $\begin{array}{l}\text { Night:Day } \\
\text { Size Ratio }\end{array}$ & $\begin{array}{l}\text { Centroid } \\
\text { Separation } \\
\text { (m) }\end{array}$ & $\begin{array}{l}\text { Time of } \\
\text { Day }\end{array}$ & $\begin{array}{l}\text { Size } \\
\left(\mathrm{km}^{2}\right)\end{array}$ & $\begin{array}{l}\text { Seagrass } \\
\%\end{array}$ & $\begin{array}{l}\text { Coral } \\
\text { Reef } \\
\%\end{array}$ & $\begin{array}{l}\text { Pavement } \\
\%\end{array}$ & $\begin{array}{l}\text { Other } \\
\%\end{array}$ \\
\hline \multirow[t]{2}{*}{24797} & 0.24 & 0.24 & 64 & Day & 0.041 & 71.2 & 0 & 28.8 & 0 \\
\hline & & & & Night & 0.010 & 84.3 & 0 & 15.7 & 0 \\
\hline \multirow[t]{2}{*}{45334} & 0.09 & 0.18 & 257 & Day & 0.096 & 89.4 & 10.6 & 0 & 0 \\
\hline & & & & Night & 0.017 & 90.9 & 9.1 & 0 & 0 \\
\hline \multirow[t]{2}{*}{45337} & 0.15 & 0.21 & 274 & Day & 0.167 & 64.4 & 21.7 & 13.8 & 0.1 \\
\hline & & & & Night & 0.036 & 69.8 & 7.8 & 22.5 & 0 \\
\hline \multirow[t]{2}{*}{45338} & 0.07 & 0.07 & 97 & Day & 0.195 & 89.6 & 9.8 & 0.6 & 0 \\
\hline & & & & Night & 0.014 & 100 & 0 & 0 & 0 \\
\hline \multirow[t]{2}{*}{45339} & 0.30 & 0.42 & 113 & Day & 0.071 & 94.1 & 5.9 & 0 & 0 \\
\hline & & & & Night & 0.030 & 93.9 & 6.1 & 0 & 0 \\
\hline \multirow[t]{2}{*}{59271} & 0.36 & 0.36 & 47 & Day & 0.049 & 91.2 & 0 & 8.8 & 0 \\
\hline & & & & Night & 0.018 & 91.7 & 0 & 8.3 & 0 \\
\hline
\end{tabular}

All individuals used a combination of seagrass, reef, and pavement habitats, with no other habitat types appearing in home ranges (Table 2). Benthic cover of $95 \%$ MCPs had a mean of $84.3 \%$ seagrass, $6.9 \%$ reef, and $8.9 \%$ pavement; corresponding mean HSI values were $1.6,1.2$, and 1 , respectively. HSI values for seagrass were significantly more than an even ratio of $1(V=21, p=$ $0.03)$, but were not significantly different from 1 for coral reef $(V=12, p=0.8)$ or pavement $(V=10.5, p=1)$. As for daytime and nighttime activity spaces, each was dominated by seagrass habitats, but most also included some proportion of reef and/or pavement (Table 3). Daytime activity spaces had a mean coverage of $83.3 \%$ seagrass, $8.0 \%$ reef, and $8.7 \%$ pavement, while nighttime activity spaces had a mean coverage of $88.4 \%$ seagrass, $3.8 \%$ reef, and $7.8 \%$ pavement. There was suggestive evidence that seagrass coverage was higher in nighttime spaces than daytime spaces $(V=1, p=0.06)$, but there was no difference for reef $(V=9, p=0.2)$ or pavement $(V=7, p=0.6)$.

There was no evidence that $L$. analis select for specific temperature ranges; instead, tagged individuals utilized available temperatures equitably $\left(D_{75}=0.173, p=0.21\right)$. Space use patterns over time showed significant differences across days $\left(F_{8579}=\right.$ $27.1, p=0.03)$ but not across months $\left(F_{272}=1.37, p=0.23\right)$, indicating variability in movement patterns but no apparent seasonal shifts.

\section{Discussion}

The six L. analis included in analyses showed high site fidelity to Brewers Bay, with home ranges that rarely overlapped, were highly variable in size and location among individuals, and together, covered the majority of Brewers Bay. This result is expected due to the territorial nature of $L$. analis, which defend their home range center [23], although it was not discussed in previous acoustic telemetry studies. Territoriality of home ranges is common in many species of coral reef fish and is usually associated with reproductive behavior of surgeonfish [53], parrotfish [54], and groupers [55, 56], but has also been observed during nonreproductive periods in the dusky grouper, Epinephelus marginatus [57], and by damselfish in defense of food resources [58]. 
All home ranges in this study covered a combination of entirely seagrass, coral reef, and pavement habitats, as expected for a generalist predator like $L$. analis, which frequently feeds in sand, seagrass, and coral rubble near reefs [26]. Home range habitat composition was dominated by seagrass for all individuals, who showed a preference for this habitat beyond its prevalence. The only receivers in the Brewers Bay array without any detections from an individual $L$. analis through the course of the study were the four forming the southernmost row along the airport runway. These receivers were in deep bare sand (23-27 m), an unfavorable habitat type for this species as it provides limited food and structure.

\section{Home Range Characteristics}

Five of the six $L$. analis were detected daily, and all had RI values of greater than 0.9 . Two individuals $(45334,45338)$ that departed from Brewers Bay were detected at separate acoustic arrays at known multi-species spawning aggregation sites of Tampo, south of St. John, and the Grammanik Bank, south of St. Thomas. One was only detected at Tampo (45334), and the other (45338) was detected at both sites within the span of a week, before returning to Brewers Bay. These absences followed the full moon during June and July, when peak spawning of L. analis is known to occur [21,59], suggesting that these fish migrated for reproductive purposes. It was interesting to note, however, that nearly all other fish showed an increase in activity at the beginning of spawning season (April) and swam to the receivers on the south side of the airport runway each afternoon for a few hours on days that coincided with full moon periods. These fish were all were of reproductive size ( $>28 \mathrm{~cm}$ fork length; [30]) and may have spawned nearby their home ranges, as has been shown for dog snapper (Lutjanus jocu) [60].

Two fish were tracked during the two Category 5 hurricanes (Irma and Maria) that struck the USVI in September 2017. While detection rates dropped during the storms, these individuals were still present in Brewers Bay, and did not temporarily retreat to deeper water, as sharks, sea turtles, and stingrays have been observed doing before a storm [61, 62].

The average size of $95 \%$ MCPs was $0.103 \pm 0.028 \mathrm{~km}^{2}$ and the average $95 \%$ BBMM was $0.168 \pm 0.028 \mathrm{~km}^{2}$, which were smaller than previous estimates for this species. The $7.64 \mathrm{~km}^{2}$ estimate from Farmer and Ault [33] included home range, spawning site, and the migration corridor between them; doing so in this study would increase MCP sizes from 0.126 to $18 \mathrm{~km}^{2}(45334)$ and from 0.190 to $69.7 \mathrm{~km}^{2}$ (45338). Feeley et al. [34] excluded spawning sites from home range estimates, but still found a home range of a minimum of $1.97 \mathrm{~km}^{2}$, larger than any in this study. While array coverage in that study was sparse to cover a larger area than described here and may not be directly comparable, it may be that a different spatial configuration of habitat types in Florida may necessitate a larger home range to access a similar set of resources [63].

There was high variation in the estimated size of home ranges among individuals, and different estimation methods produced significantly differently sized home ranges. MCPs, while easy to calculate, do not take into account the density of usage within them or any indication of directed movement pathways [50]. BBMMs are better at accounting for error in location estimates, and the output is less sensitive to outliers and highlights the densest areas of usage and pathways between them [49]. In this study, BBMMs seemed to provide more precise, and typically larger, estimations of home range than MCPs. For two individuals (45334 and 45337), the BBMM showed two hotspots with a connection between them that were not apparent in the MCPs, portraying movement pathways along reef edges and between patch reefs.

While fish movement patterns were variable from day to day, there were no significant seasonal changes in individual space use patterns across months. Although the time period tested was only seven months and included the coldest water temperatures of the year, there were no apparent temperature associations when considering the entire study period. Since minimum and maximum annual temperatures in Brewers Bay are within $7^{\circ} \mathrm{C}$ and are fairly spatially homogeneous, temperature variation may not be large enough to warrant a behavioral change, unlike estuaries where temperature is a primary factor affecting fish distribution [64].

\section{Diel Patterns}

Tracked fish moved farther from their home range center during the day than at night but showed high overlap of daytime and nighttime spaces in both location and habitat composition, with at least $56 \%$ of each nighttime activity space overlapping with the corresponding daytime activity space. There may have been higher usage of seagrass at night, but there was less

Page 9/18 
differentiation from daytime usage than observed by Hitt et al. [4] in species of a similar trophic group (schoolmaster snapper, Lutjanus apodus, and bluestriped grunts, Haemulon sciurus), which used larger nighttime activity spaces that were clearly separated from daytime spaces, with a clear shift from high-relief hard substratum habitats to low-relief soft substratum habitats. Hitt et al. actively tracked fish, which allowed for a much finer estimate of space use and had a greater power to detect differences. The $24 \mathrm{~h}$ tracking period likely did not encapsulate day-to-day variations [33], therefore, the stark differences between daytime and nighttime activity spaces may become less detectable with the lower spatial resolution and added daily variance present in this study. Alternatively, while $L$. analis and $L$. apodus are closely related, these species may exhibit behavioral variation due to differential predation risk and use of different habitat types to meet dietary needs [65]. Diet studies have suggested that unlike other species of snapper, L. analis forage opportunistically throughout the day [26, 27], which would explain the habitat similarity between daytime and nighttime activity spaces. Furthermore, the larger size of the daytime activity space in combination with the low overlap of core use areas suggests a regular patrol of the edges of a territory to defend against competition for valuable resources. Future studies could use a VEMCO Positioning System (VPS) array, which has more accuracy in detection locations, to clarify whether animal behavior or methodology is the source of the discrepancies between these studies.

\section{Conclusions}

Despite the small sample size of six $L$. analis, this study presents the most comprehensive home range description to date on this economically important Caribbean reef fish. Home range estimates demonstrate usage of multiple habitat types within a relatively small area by individual adult $L$. analis, with the additional need for offshore spawning sites. Seagrass beds, which are an important food source for snapper and other reef fish, can change quickly in size and coverage with shifting environmental conditions or disturbances [66], and while the effects of natural disasters such as hurricanes cannot be prevented, disturbances from human activity could be limited by prohibiting specific practices, such as anchoring in known seagrass beds and along reef edges. As habitat variability in an area is an important component of its suitability for many species, spatial management efforts should focus on zones with proximity to multiple habitat types [67], including mangroves and seagrasses as well as nearshore and offshore coral reefs, which support coral reef fish across diel movements and ontogenetic stages [24, 63, 65].

Quantifying specific characteristics of $L$. analis movements, including home range size, habitat requirements, and diel movement patterns, are necessary to implement directed management at an appropriate scale. Although $L$. analis are highly mobile during reproductive periods, they show site fidelity to a relatively small home range during all other periods, indicating that effective management of this species should target home ranges and spawning aggregations separately. While small marine protected

areas of less than $1 \mathrm{~km}^{2}$ placed over reef and seagrass habitats where $L$. analis are known to reside could protect more than $95 \%$ of the space usage of a few individuals, many areas have a relatively low or unknown population density, warranting a more effective use of resources. For example, restrictions on bottom gear and seasonal closures of aggregation fishing during reproductive periods, with cooperation from local artisanal fishers, may be better approaches for targeted management of $L$. analis to maintain its ecological and economic benefits.

\section{Declarations}

\section{Acknowledgements}

We thank Melissa Kimble for advice on data analysis and the creation of the habitat map, and Sennai Habtes and Christopher Lowe for help with data analysis and writing improvements. We also thank Mara Duke, Danielle Lasseigne, Kaleigh Schlender, John Cassell, Mareike Duffing-Romero, Damon Green, Michele Donihe, Allie Durdall, Tanya Ramseyer, Colin Howe, Elizabeth Brown, Kristen Ewen, Amelie Jensen, Sydney Nick, and Lora Johansen for assistance in the field.

This is contribution \#XXX to University of the Virgin Islands Center for Marine and Environmental Studies.

\section{Ethics Approval}


All tagging and tracking methods for $L$. analis presented in this manuscript were approved by the University of the Virgin Islands Institutional Animal Care and Use Committee (IRB \#747807-1).

\section{Consent for publication}

Not applicable.

\section{Availability of data and materials}

The datasets used and/or analyzed during the current study or associated R code are available from the corresponding author on reasonable request.

\section{Competing interests}

The authors declare that they have no competing interests.

\section{Funding}

This study was made possible by the Virgin Islands Experimental Program to Stimulate Competitive Research (VI-EPSCoR), supported by NSF Grant \#1355437.

\section{Authors' Contributions}

RSN conceived the idea and secured the funding; RSN, JJ, and SLH designed the methodology; SLH, JJ, and RSN collected the data; SLH and JJ analyzed the data; SLH led the writing of the manuscript. All authors contributed to the drafts and gave final approval for publication. All authors read and approved the final manuscript.

\section{References}

1. Hitt S, Pittman SJ, Brown KA. Tracking and mapping sun-synchronous migrations and diel space use patterns of Haemulon sciurus and Lutjanus apodus in the US Virgin Islands. Environ Biol Fishes. 2011;75(4).

2. Vaudo JJ, Heithaus MR. Spatiotemporal variability in a sandflat elasmobranch fauna in Shark Bay, Australia. Mar Biol. 2009;156:2579-90.

3. Barrows EM. Animal Behavior Desk Reference. 2nd ed. Boca Raton: CRC Press; 1996.

4. Hitt S, Pittman SJ, Nemeth RS. Diel movements of fishes linked to benthic seascape structure in a Caribbean coral reef ecosystem. Mar Ecol Prog Ser. 2011;427:275-91.

5. Winemiller KO, Jepsen DB. Effects of seasonality and fish movement on tropical river food webs. J Fish Biol. 1998;53:26796.

6. Grober-Dunsmore R, Frazer TK, Lindberg WJ, Beets JP. Reef fish and habitat relationships in a Caribbean seascape: the importance of reef context. Coral Reefs. 2007;26:201-16.

7. Simpfendorfer CA, Heupel MR, Hueter RE. Estimation of short-term centers of activity from an array of omnidirectional hydrophones and its use in studying animal movements. Can J Fish Aquat Sci. 2002;59:23-32.

8. Espinoza M, Farrugia TJ, Webber DM, Smith F, Lowe CG. Testing a new acoustic telemetry technique to quantify long-term, fine-scale movements of aquatic animals. Fish Res. 2011;108:364-71.

9. Zeller DC. Ultrasonic telemetry: its application to coral reef fisheries research. Fish Bull. 1999;97(4):1058-65.

10. Currey LM, Heupel MR, Simpfendorfer CA, Williams AJ. Assessing fine-scale diel movement patterns of an exploited coral reef fish. Anim Biotelemetry. 2015;3:41.

11. Monaco ME, Friedlander AM, Hile SD, Pittman SJ, Boulon RH. The coupling of St. John, US Virgin Islands marine protected areas based on reef fish habitat affinities and movements across management boundaries. In: Riegl B, Dodge RE, editors. Proceedings of the 11th International Coral Reef Symposium; 2008 Jul 7-11; Ft. Lauderdale, Florida. Davie, FL: Nova Southeastern University National Coral Reef Institute; 2008. p. 1022-5. 
12. Friedlander AM, Clark RD, Pittman SJ, Beets JP, Boulon RH, Callender R, et al. Fish movement patterns in Virgin Islands National Park, Virgin Islands Coral Reef National Monument and adjacent waters. Silver Spring: NOAA/National Centers for Coastal Ocean Science; 2013. Jul. 104 pp. NOAA Technical Memorandum NOS NCCOS 172.

13. Lowe CG, Topping DT, Cartamil DP, Papastamatiou YP. Movement patterns, home range, and habitat utilization of adult kelp bass Paralabrax clathratus in a temperate no-take marine reserve. Mar Ecol Prog Ser. 2003;256:205-16.

14. Legare B, Kneebone J, DeAngelis B, Skomal G. The spatiotemporal dynamics of habitat use by blacktip (Carcharhinus limbatus) and lemon (Negaprion brevirostris) sharks in nurseries of St. John, United States Virgin Islands. Mar Biol. 2015;162(3):699-716.

15. Friedlander AM, Monaco ME. Acoustic tracking of reef fishes to elucidate habitat utilization patterns and residence times inside and outside marine protected areas around the Island of St. John, USVI. Silver Spring: NOAA/National Centers for Coastal Ocean Science; 2007. Oct. 48 p. NOAA Technical Memorandum NOS NCCOS 63.

16. Rowell TJ, Nemeth RS, Sharer MT, Appeldoorn RS. Fish sound production and acoustic telemetry reveal behaviors and spatial patterns associated with spawning aggregations of two Caribbean groupers. Mar Ecol Prog Ser. 2015;518:239-54.

17. Grober-Dunsmore R, Frazer TK, Beets JP, Lindberg WJ, Zwick P, Funicelli NA. Influence of landscape structure on reef fish assemblages. Landscape Ecol. 2008;23:37-53.

18. Pittman SJ, Caldow C, Hile SD, Monaco ME. Using seascape types to explain the spatial patterns of fish in the mangroves of SW Puerto Rico. Mar Ecol Prog Ser. 2007;348:273-84.

19. Topping DT, Szedlmayer ST. Home range and movement patterns of red snapper (Lutjanus campechanus) on artificial reefs. Fish Res. 2011;112:77-84.

20. Lindeman K, Anderson W, Carpenter KE, Claro R, Cowan J, Padovani-Ferreira B, et al. Lutjanus analis. In: The IUCN. Red List of Threatened Species 2016. The International Union for the Conservation of Nature. 2016.

http://dx.doi.org/10.2305/IUCN.UK.2016-1.RLTS.T12416A506350.en.

21. Heyman WD, Kjerfve B. Characterization of transient multi-species reef fish spawning aggregations at Gladden Spit, Belize. Bull Mar Sci. 2008;83(3):531-51.

22. Kojis BL, Quinn NJ. Validation of a mutton snapper (Lutjanus analis) spawning aggregation in the Mutton Snapper Seasonal Closed Area, St. Croix, U.S. Virgin Islands. In: Acosta A, Creswell L, editors. Proceedings of the 62nd Gulf and Caribbean Fisheries Institute. Cumana, Venezuela: Gulf and Caribbean Fisheries Institute; 2009. p. 267-272.

23. Mueller KW, Dennis GD, Eggleston DB, Wicklund RI. Size-specific social interactions and foraging styles in a shallow water population of mutton snapper, Lutjanus analis (Pisces: Lutjanidae), in the central Bahamas. Environ Biol Fishes. 1994;40:175-88.

24. Cocheret de la Morinière E, Nagelkerken I, van der Velde G, Pollux BJ, Hemminga MA, Huiskes AH. Ontogenetic dietary changes of coral reef fishes in the mangrove-seagrass-reef continuum: stable isotopes and gut-content analysis. Mar Ecol Prog Ser. 2003;246:279-89.

25. Farmer NA, Ault JS. Modeling coral reef fish home range movements in Dry Tortugas, Florida. Sci World J. 2014;2014:14.

26. Randall JE. Food habits of reef fishes of the West Indies. Stud Trop Oceanogr. 1967;5:665-847.

27. Duarte LO, García CB. Diet of the mutton snapper Lutjanus analis (Cuvier) from the Gulf of Salamanca, Colombia, Caribbean Sea. Bull Mar Sci. 1999;65(2):453-65.

28. Freitas MO, Abilhoa V, da Costa e Silva GH. Feeding ecology of Lutjanus analis (Teleostei: Lutjanidae) from Abrolhos Bank, Eastern Brazil. Neotrop Ichthyol. 2011;9(2):411-8.

29. Froese R, Pauly D, editors. FishBase. 2019. http://www.fishbase.org. Accessed 21 Apr 2020.

30. Teixeira SF, Duarte YF, Ferreira BP. Reproduction of the fish Lutjanus analis (mutton snapper; Perciformes: Lutjanidae) from Northeastern Brazil. Rev Biol Trop. 2010;58(3):791-800.

31. Kramer DL, Chapman MR. Implications of fish home range size and relocation for marine reserve function. Environ Biol Fishes. 1999;55:65-79.

32. Sale PF, Cowen RK, Danilowicz BS, Jones GP, Kritzer JP, Lindeman KC, et al. Critical science gaps impede use of no-take fishery reserves. Trends Ecol Evol. 2005;20(2):74-80.

Page 12/18 
33. Farmer NA, Ault JS. Grouper and snapper movements and habitat use in Dry Tortugas, Florida. Mar Ecol Prog Ser. 2011;433:169-84.

34. Feeley MW, Morley D, Acosta A, Barbera P, Hunt J, Switzer T, et al. Spawning migration movements of Mutton Snapper in Tortugas, Florida: Spatial dynamics within a marine reserve network. Fish Res. 2018;204:209-23.

35. Costa B, Kendall M, Edwards K, Kagesten G. Benthic habitats of Fish Bay, Coral Bay and the St. Thomas East End Reserve. Silver Spring: NOAA/National Centers for Coastal Ocean Science; 2013 Nov. 68 p. NOAA Technical Memorandum NOS NCCOS 175.

36. Kendall MS, Monaco ME, Buja KR, Christensen JD, Kruer CR, Finkbeiner M. (2001). Methods used to map the benthic habitats of Puerto Rico and the U.S. Virgin Islands. Silver Spring, MD: NOAA/National Centers for Coastal Ocean Science; 2001. 45 p. NOAA Technical Memorandum NOAA NCCOS CCMA 152.

37. Farmer NA, Ault JS, Smith SG, Franklin EC. Methods for assessment of short-term coral reef fish movements within an acoustic array. Mov Ecol. 2013;1(7):1-13.

38. Jossart J, Nemeth RS, Primack A, Stolz R. Extreme passive acoustic telemetry detection variability on a mesophotic coral reef, United States Virgin Islands. Mar Biol. 2017;164(9):180.

39. Kessel ST, Cooke SJ, Heupel MR, Hussey NE, Simpfendorfer CA, Vagle S, et al. A review of detection range testing in aquatic passive acoustic telemetry studies. Rev Fish Biol Fish. 2014;24(1):199-218.

40. Heupel MR, Reiss KL, Yeiser BG, Simpfendorfer CA. Effects of biofouling on performance of moored data logging acoustic receivers. Limnol Oceanogr Methods. 2008;6:327-35.

41. VEMCO. VEMCO User Environment (VUE) Software. Halifax: AMIRIX Systems; 2016. https://www.vemco.com.

42. Akins JL, Morris JA, Green SJ. In situ tagging technique for fishes provides insight into growth and movement of invasive lionfish. Ecol Evol. 2014;4(19):3768-77.

43. R Core Team. R: A language and environment for statistical computing. Vienna, Austria: R Foundation for Statistical Computing; 2020. https://www.R-project.org.

44. RStudio Team. RStudio: Integrated Development for R. Boston: RStudio, Inc; 2019. http://www.rstudio.com.

45. US Naval Observatory. Sun or moon rise/set table for one year. http://aa.usno.navy.mil/data/docs/RS_OneYear.php (2011). Accessed 6 Feb 2017.

46. VEMCO. Collision Calculator. Halifax. AMIRIX Systems; 2017. https://vemco.com/collision-calculator.

47. Afonso P, Fontes J, Holland KN, Santos RS. Social status determines behaviour and habitat usage in a temperate parrotfish: Implications for marine reserve design. Mar Ecol Prog Ser. 2008;359:215-27.

48. Calenge $C$. The package "adehabitat" for the R software: A tool for the analysis of space and habitat use by animals. Ecol Model. 2006;197:516-19.

49. Horne JS, Garton EO, Krone SM, Lewis JS. Analyzing animal movements using Brownian bridges. Ecology. 2007;88(9):235463.

50. Rogers KB, White GC. Analysis of movement and habitat use from telemetry data. In: Guy CS, Brown ML, editors. Analysis and Interpretation of Freshwater Fisheries Data. Bethesda: American Fisheries Society; 2007. pp. 625-76.

51. Winter JD, Ross MJ. Methods in analyzing fish habitat utilization from telemetry data. In: Armantrout N, editor. Proceedings of the Symposium on Acquisition and Utilization of Aquatic Habitat Inventory Information. Bethesda, MD: American Fisheries Society Western Division; 1982. p. 273-279.

52. Oksanen J, Blanchet FG, Friendly M, Kindt R, Legendre P, McGlinn D, et al. (2018). vegan: Ecology Package. R package version 2.5-6. 2019. https://CRAN.R-project.org/package=vegan.

53. Claisse JT, Clark TB, Schumacher BD, McTee SA, Bushnell ME, Callan CK, et al. Conventional tagging and acoustic telemetry of a small surgeonfish, Zebrasoma flavescens, in a structurally complex coral reef environment. Environ Biol Fishes. 2011;91:185-201.

54. Welsh JQ, Bellwood DR. Spatial ecology of the steephead parrotfish (Chlorurus microrhinos): An evaluation using acoustic telemetry. Coral Reefs. 2012;31:55-65. 
55. Sadovy Y, Colin PL, Domeier ML. Aggregation and spawning in the tiger grouper, Mycteroperca tigris (Pisces: Serranidae). Copeia 1994:511-516.

56. Shapiro DY, Sadovy Y, McGehee MA. Size, composition, and spatial structure of the annual spawning aggregation of the red hind, Epinephelus guttatus (Pisces: Serranidae). Copeia 1993:399-406.

57. Koeck B, Pastor J, Saragoni G, Dalias N, Payrot J, Lenfant P. Diel and seasonal movement pattern of the dusky grouper Epinephelus marginatus inside a marine reserve. Mar Environ Res. 2014;94:38-47.

58. Itzkowitz M. Heterospecific intruders, territorial defense and reproductive success in the beaugregory damselfish. J Exp Mar Biol Ecol. 1990;140:49-59.

59. Burton ML, Brennan KJ, Muñoz RC, Parker RO. Preliminary evidence of increased spawning aggregations of mutton snapper (Lutjanus analis) at Riley's Hump two years after establishment of the Tortugas South Ecological Reserve. Fish Bull. 2005;103(2):404-10.

60. Krajewski JP, Bonaldo RM. Spawning out of aggregations: record of a single spawning dog snapper pair at Fernando de Noronha Archipelago, Equatorial Western Atlantic. Bull Mar Sci. 2005;77:165-7.

61. Heupel MR, Simpfendorfer CA, Hueter RE. Running before the storm: Blacktip sharks respond to falling barometric pressure associated with Tropical Storm Gabrielle. J Fish Biol. 2003;63:1357-63.

62. Matley JK, Eanes S, Nemeth RS, Jobsis PD. Vulnerability of sea turtles and fishes in response to two catastrophic Caribbean hurricanes, Irma and Maria. Sci Rep. 2019;9:1-15.

63. Nagelkerken I, Bothwell JB, Nemeth RS, Pitt JM, van der Velde G. Interlinkage between Caribbean coral reefs and seagrass beds through feeding migrations by grunts (Haemulidae) depends on habitat accessibility. Mar Ecol Prog Ser.

2008;368:155-64.

64. Harrison TD, Whitfield AK. Temperature and salinity as primary determinants influencing the biogeography of fishes in South African estuaries. Estuar Coast Shelf Sci. 2006;66:335-45.

65. Cocheret de la Morinière E, Pollux BJ, Nagelkerken I, van der Velde G. Diet shifts of Caribbean grunts (Haemulidae) and snappers (Lutjanidae) and the relation with nursery-to-coral reef migrations. Estuar Coast Shelf Sci. 2003;57:1079-89.

66. Fourqurean JW, Rutten LM. The impact of Hurricane Georges on soft-bottom, back reef communities: Site- and speciesspecific effects in south Florida seagrass beds. Bull Mar Sci. 2004;75:239-57.

67. Pittman SJ, Monaco ME, Friedlander AM, Legare B, Nemeth RS, Kendall MS, et al. Fish with chips: tracking reef fish movements to evaluate size and connectivity of Caribbean marine protected areas. PLoS One. 2014;9:5.

\section{Figures}




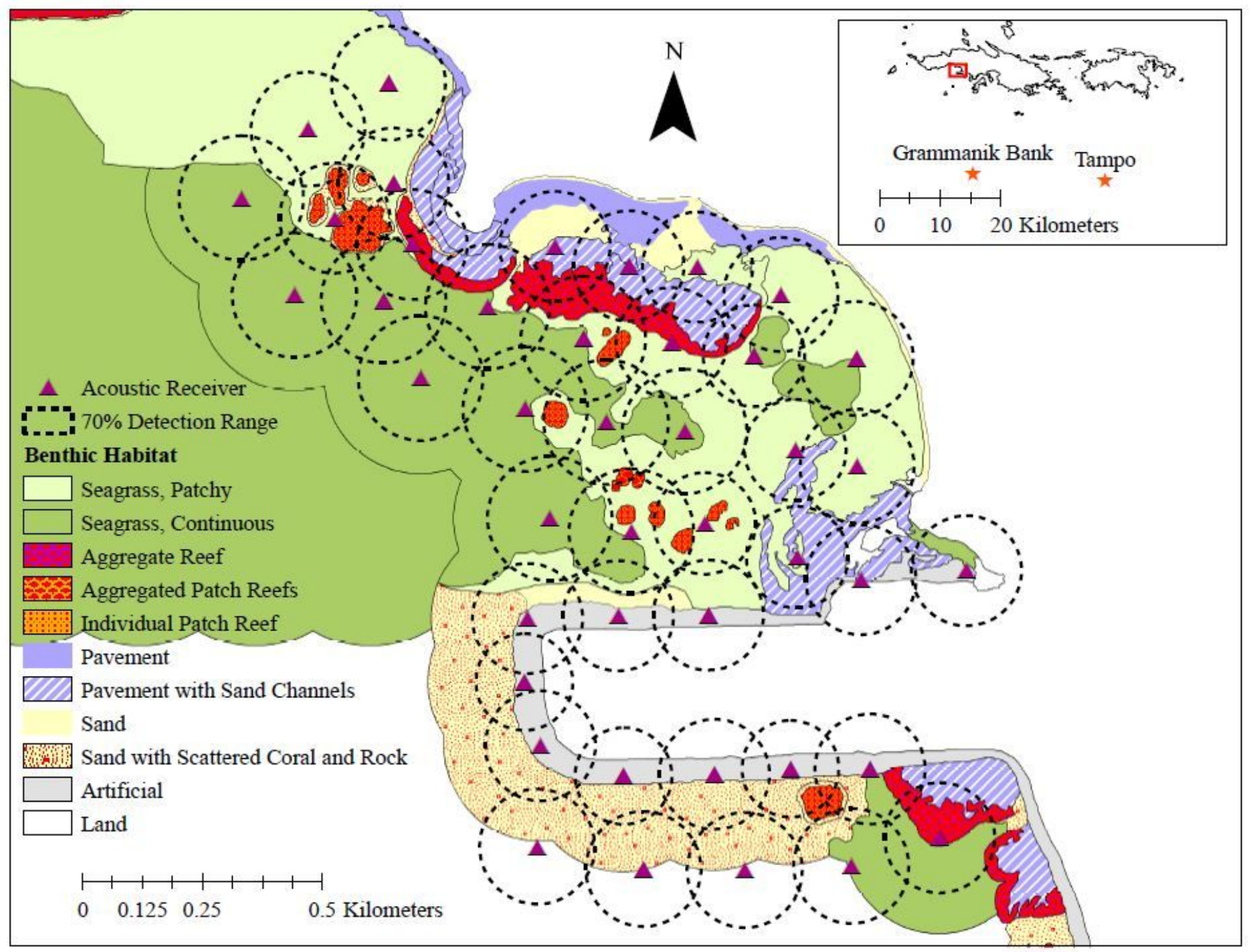

Figure 1

Map of Brewers Bay, with inset showing location on St. Thomas, USVI, and nearby Lutjanus analis spawning sites at Grammanik Bank and Tampo. Triangles represent locations of $43 \mathrm{VEMCO}$ acoustic receivers, with circles representing $70 \%$ detection range (for V13 transmitters; varies by receiver: 101-120 m). Benthic habitat maps were manually digitized by Melissa Kimble (unpublished data). 


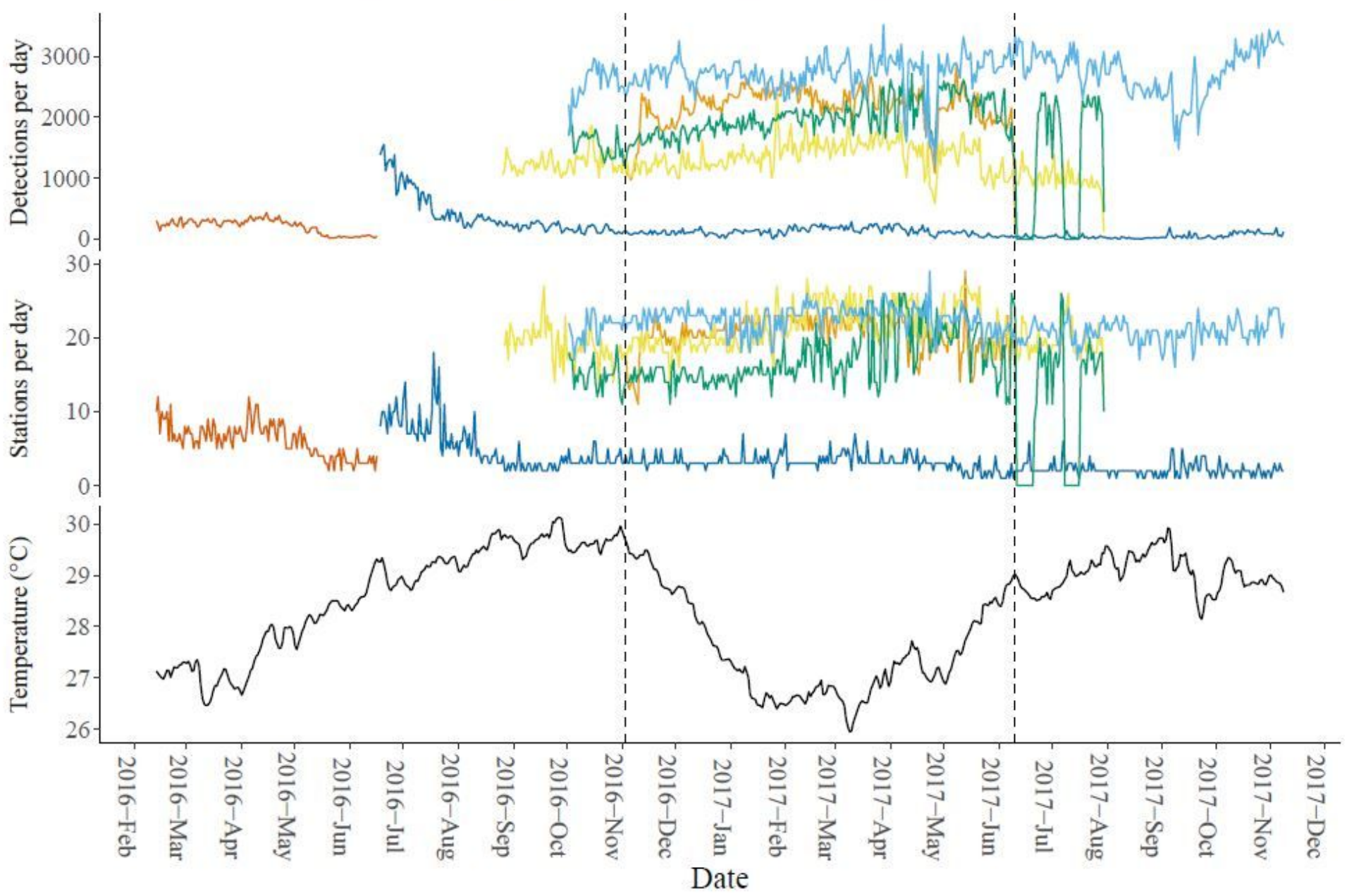

Figure 2

Activity of tagged Lutjanus analis, measured as number of detections per day (upper panel) and number of receiver stations visited per day (middle panel) in Brewers Bay, St. Thomas, USVI, between February 2016 and November 2017. Lower panel shows average temperature $\left({ }^{\circ} \mathrm{C}\right)$ across the bay during the study period. Vertical dashed lines delineate the period used in the PERMANOVA. 

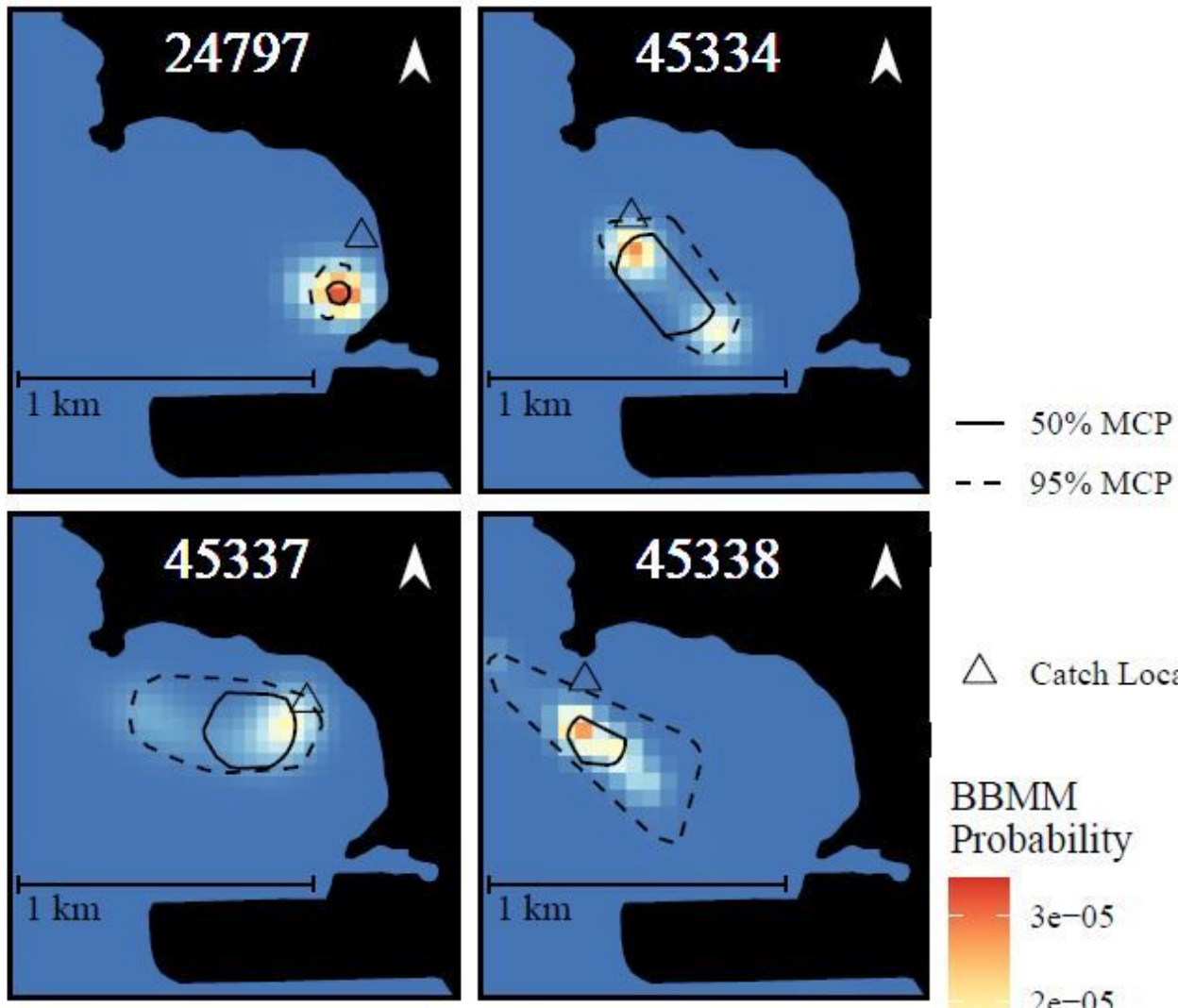

$--95 \% \mathrm{MCP}$
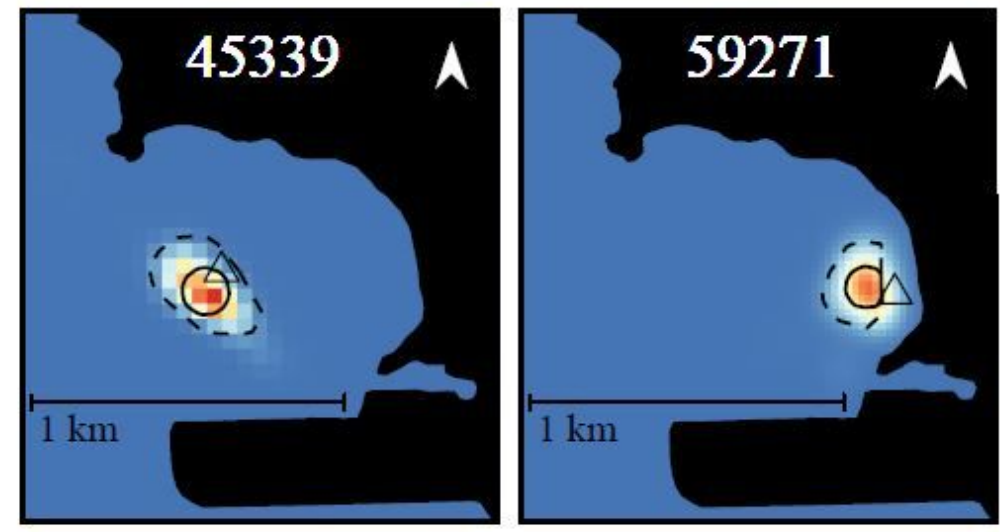

$\triangle$ Catch Location

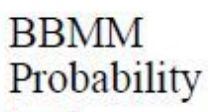

Probability

$3 e-05$

$2 \mathrm{e}-05$

$1 \mathrm{e}-05$

\section{Figure 3}

Estimated home ranges of six Lutjanus analis tracked in Brewers Bay, St. Thomas, USVI, between February 2016 and November 2017. Color denotes probability of occurrence as estimated by Brownian bridge movement models (BBMMs); dashed lines represent $95 \%$ minimum convex polygons (MCPs) and solid lines represent core use areas (50\% MCPs). Triangle indicates catch and release location for each fish. 

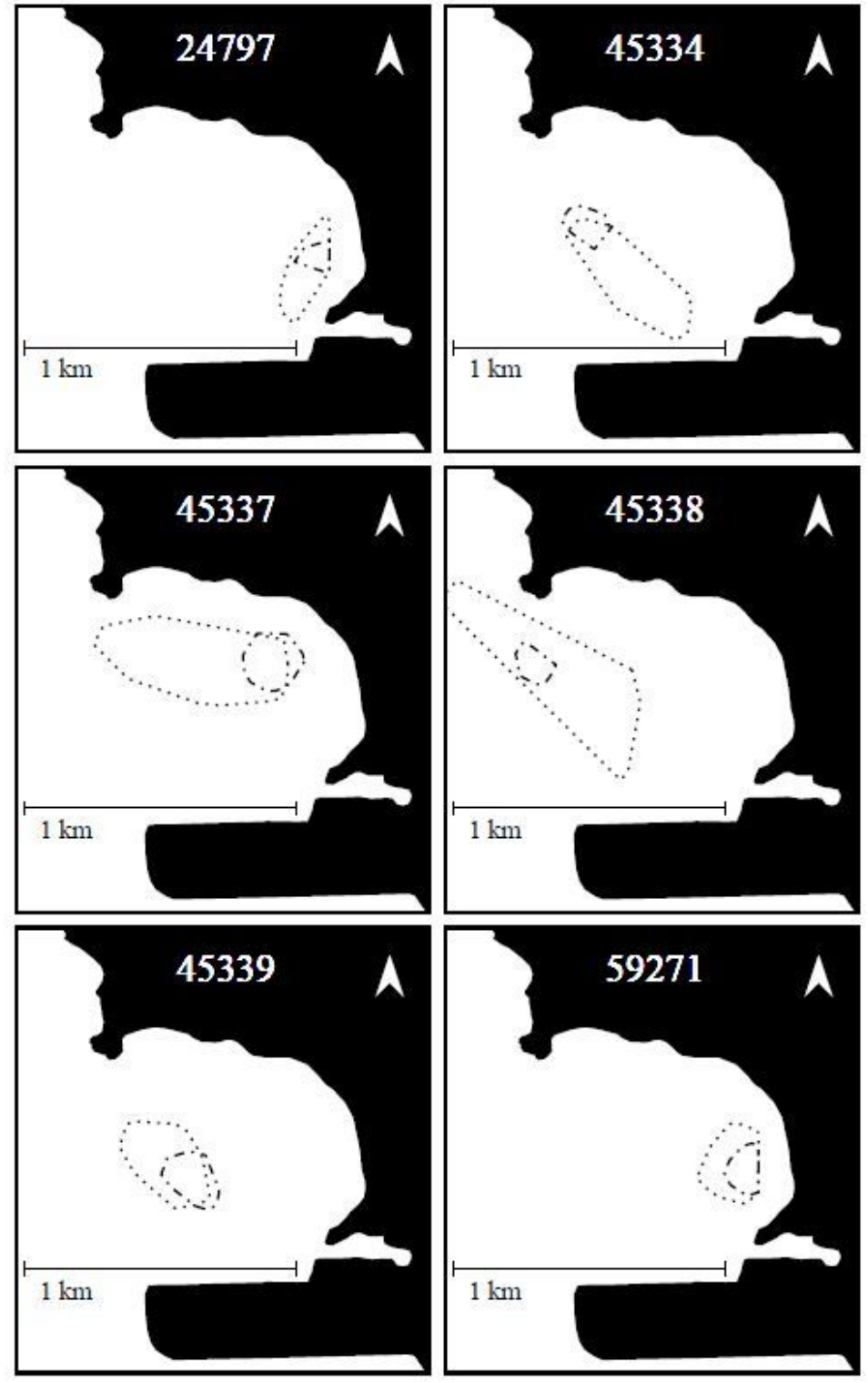

-... Daytime $95 \%$ MCP

-.- Nighttime $95 \%$ MCP

Figure 4

Daytime (dotted) and nighttime (dot-dashed) activity spaces for each tracked Lutjanus analis in Brewers Bay, St. Thomas, created using 95\% minimum convex polygons (MCPs). 